Алсу Флюровна Исмагилова

Россия, Бачкирский государственный педагогический университет

им. М. Акмулльь

\title{
Пунктуация как способ организации диалога в рекламном тексте ${ }^{1}$
}

Ключевые слова: пунктуация, реклама, креолизованная реклама, рекламный текст. Key words: punctuation, advertising, creolized advertising, advertising text.

\begin{abstract}
This article analyses the communication aspect of punctuation marks in advertising texts. External advertising of the Ufa, Republic of Bashkortostan of the Russian Federation is used as material for this work. The study implemented such methods of linguistic analysis as the sampling method used to collect the material, and the method of linguistic observation. The analysis highlighted main punctuation techniques used by advertisers to construct advertising messages as a dialogue with the target audience - parcelling, interrogative sentences, exclamatory sentences, and sentences with punctuation marks such as dash and ellipsis.
\end{abstract}

Коммуникативный аспект пунктуации рассматривался разными исследователями. Над этим вопросом трудились такие лингвисты, как Д.Э. Розенталь, Н.Н. Кохтев, Н.С. Валгина, Е.О. Захарова, М.А. Марышева, О.А. Селеменева и др. Актуальность данного направления, как отмечает Е.О. Захарова, обусловлена новыми тенденциями к употреблению пунктуационных знаков, которые вызваны «естественным развитием пунктуационной системы, либерализацией письменного языка, влиянием электронной коммуникации и совершенствованием полиграфических технологий» [Zaharova 2009].

ПУНКТУАЦИЯ (ср. лат. punctuatio, от лат. punctum - точка) - 1) система графических внеалфавитных знаков (знаков препинания), образующих вместе с графикой

1 Работа выполнена при финансовой поддержке Конкурса на предоставление грантов Главы Республики Башкортостан в форме субсидий, направленных на сохранение и развитие государственных языков Республики Башкортостан и языков народов Республики Башкортостан, проект № 1470 («Русский язык как основа культурной и социальной интеграции в полиэтническом пространстве»). 
и орфографией основные средства письменного языка; главное назначение П. членение и графическая организация письменного (печатного) текста [LÈS 2002: 406].

Н.С. Валгина отмечала, что пунктуация играет немаловажную роль в языке, а именно «она „осмысливает” письменный текст, доносит его до читающего с тем содержанием, которое было задумано пишущим, и только благодаря пунктуации пишущий и читающий достигают единства в восприятии содержательной стороны текста» [Valgina 1979: 11]. Данное высказывание применимо к современной креолизованной рекламе, поскольку невербальная её часть зачастую требует вербального объяснения, так как обе они представляют из себя сложное целое, оказывающее различные воздействия на потенциальную целевую аудиторию.

В составе креолизованного рекламного текста (РТ) пунктуация, казалось бы, отходит на второй план, уступая место визуальной части баннера, целью которой является привлечение внимания, однако одним рисунком зачастую невозможно объяснить суть рекламного сообщения, и композиция креолизованного текста требует объяснения. Это же отмечали Д.Э. Розенталь и Н.Н. Кохтев: «Если реклама сначала привлекает читателя или слушателя своей эмоциональной стороной, то затем она должна заинтересовать его своим содержанием, вызвать ту или иную реакцию, стимулировать определенное эмоциональное состояние» [Rozental', Kohtev 1981: 13]. Задача стимулировать адресата на покупку отводится именно тексту, который раскрывает самую суть содержания рекламного послания. Особенностью подобного стимулирования являются экспрессивность и диалогичность современных текстов внешней рекламы, которые достигаются путем использования различных знаков препинания.

В данной статье пунктуация РТ рассматривается с точки зрения организации диалога между адресантом рекламного сообщения и адресатом. В исследовании были реализованы такие методы лингвистического анализа, как метод выборки, при помощи которого был собран материал, и метод лингвистического наблюдения. Анализ позволил выделить основные пунктуационные приемы, которые используют рекламодатели для усиления воздействия на целевую аудиторию, - парцелляцию, вопросительные конструкции, постановку тире, побудительные конструкции с восклицательным знаком, многоточие.

\section{Парцелляция}

Специфика баннерной рекламы состоит в том, что получаемая с внешних носителей информация «воспринимается одномоментно (ad hoc „К случаю”, 
здесь и сейчас по ходу движения), когда адресат не имеет ни специальной установки, ни времени на подробное ознакомление с ее содержанием» [Adâsova, Gridina 2017]. Решение данной проблемы обусловлено тем фактором, что в основе современного, переполненного информацией мира лежит клиповое мышление, представляющее собой мышление, ориентированное на обрывистое и фрагментарное восприятие информации любого вида. Термин «клиповое мышление» детерминирован английским словом clip в значении 'обрезать, отрезать, отсекать, обрывать, надрывать' [BAR 1998: 180]. Основополагающим принципом данного мышления является тот факт, что «человек воспринимает мир как серию почти не связанных между собой частей, фактов или событий» [Kupčinskaâ, Ûdalevič 2019]. Подобное восприятие обусловлено развитием информационных технологий и телевидения и, конечно, развитием рекламы, поскольку современные РТ также представляют собой фрагментарно организованную информацию, которая повсеместно преследует человека и оказывает на него воздействие. На уровне вербальных конструкций подобная фрагментарность организуется при помощи такого пунктуационного приема, как парцелляция.

ПАРЦЕЛЛЯЦИЯ (от франц. parcelle - частица) - способ речевого представления единой синтаксической структуры - предложения несколькими коммуникативно самостоятельными единицами - фразами [LÈS 2002: 369].

Данный пунктуационный прием служит средством оформления РТ в «клиповый» текст, связующим звеном которого выступает семиотика. Использование парцелляции позволяет адресантам коротко обозначить все преимущества рекламируемого товара, экономя тем самым место текста на баннере и время его прочтения адресатами, а адресатам с клиповым мышлением дает возможность успеть усвоить информацию на ходу в виде отдельных нарезанных «кадров». Например:

1) Реклама питьевой воды: Красная Горка. Родная. Любимая. Твоя.

2) Реклама строящегося жилья: На уровень выше! Клубный дом «Соты». Престижное расположение. Исторический и деловой изентр Уфы.

3) Реклама банка: Росгосстрахбанк. Кредиты. Решение о вылаче от 15 минут.

Однако парцелляция не только облегчает и ускоряет восприятие рекламы адресатами, но и может выполнять другие функции в РТ. Например, в рекламе жилого комплекса «Изумрудный», на котором изображена девушка, сложившая ладони в виде рупора и выкрикивающая фразу «Без! Первого! Взноса!», парцелляция добавляет динамичности и «оживляет» текст. Благодаря тому, что девушка буквально «кричит» с баннера во всеуслышанье, создается впечатление, будто начинается диалог между рекламодателем и рекламополучателями, где последним предлагается нечто очень выгодное. В данном случае 
приём парцелляции, оформленный при помощи восклицательных знаков, придаёт тексту волнение и ажиотаж. Таким образом, парцелляция рекламы современного глобалистского мира, ориентированного на клиповое мышление, способствует успешной коммуникации участников рекламного рынка, привыкших видеть мир в виде фрагментов и пазлов. Также стоит отметить, что благодаря активному использованию приема парцелляции в рекламе складывается не только ощущение доверия между адресантом и адресатом рекламного сообщения, но и формируется определенная привычная ситуация разговора между ними [Maryšova 2012].

\section{Вопросительные конструкции}

Также популярным пунктуационным знаком в РТ является знак вопроса. Он достаточно часто используется во внешней рекламе, поскольку: «вопросительное предложение позволяет вовлечь собеседника в диалог и либо получить у него отсутствующую у говорящего информацию, либо побудить его к определенным действиям, желательным с точки зрения автора самого вопроса» [Voejkova 2015]. К примеру:

1) Реклама строящегося жилья: Мечтаете уехать в Лондон? Яркий Лондон, все краски мира. Микрорайон Яркий.

2) Реклама супермаркета: Разрешёнка в городе? Ул. Чернышевского, 75. ООО «Гастроном №2».

3) Реклама строящегося жилья: Нужна квартира по доступной ценее? Жилой комплекс «Novalend».

Вкупе с невербальной частью креолизованного текста вопросительные конструкции создают так называемую «воронку продаж», где волнующий целевую аудиторию вопрос является «проблемагенным», в то время как невербальная часть содержит в себе готовое решение. Так, на баннерах жилых комплексов «Яркий» и «Novalend» визуальная часть содержит в себе изображение будущих жилых домов - готовое решение для мечтающих жить в Лондоне или ищущих квартиру по доступной цене покупателей. В рекламе гастронома № 2 используется несколько другой приём. Здесь «цепляющим» звеном является антоним к слову запрещёнка - разрешёнка, под которым в свете недавних политических решений об импорте продуктов и ввода на них санкций со стороны ЕС и США на территорию Российской Федерации рекламодатель транслирует целевой аудитории посыл о том, что в данном магазине можно купить любой запрещенный вышеупомянутыми странами продукт. Знак вопроса в данном случае призван внести некий ажиотаж 
в передаваемое рекламодателем сообщение, вследствие чего у целевой аудитории возникает желание посетить рекламируемый магазин.

\section{Постановка тире}

Многие рекламодатели прибегают к такому знаку, как тире. Оно позволяет ёмко, без лишних слов, передать смысл рекламного послания. К тому же, тире экономит не только время прочтения баннера, но и текстовое пространство. К данному знаку лингвисты относились неоднозначно. Так, например, известно, что Бодуэн де Куртенэ считал его «дамским знаком», или «нервным», т.к. полагал, что он попал в литературу из писем и дневников, которые в основном писали женщины. В чем-то он был прав: тире - любимый знак препинания Марины Цветаевой. А.М. Пешковский же называл тире «знаком отчаяния», поскольку его использовали в затруднительных ситуациях, когда у пишущего возникали сомнения, какой знак поставить. Однако в современной рекламе данный знак используется достаточно часто, поскольку помогает выделить наиболее важное в вербальной части креолизованного РТ и концентрирует на этом внимание читателя. Так, при отсутствии глагола усиливается интонационная динамика фразы. Например:

1) Реклама строящегося жилья: Ключи - сразу! Квартира от 1,7 млн. Жилой комплекс «Авиатор».

Отсутствие глагола создает ощущение неожиданности, показывает, что квартиру в рекламируемом новострое можно получить незамедлительно, что само по себе не характерно для строящихся жилых домов и является выгодным преимуществом. Смысловое противопоставление акцентирует выгоду, которую получает клиент при покупке рекламируемого продукта:

2) Реклама автосервиса: Доверьте свой Volkswagen профессионалам. Воскресный сервис. Мы работаем-вы отдыхаете!

В данном примере акцент при помощи противопоставления, которое образует тире, смещён именно на выгоду (возможность отдать машину на обслуживание в выходной день), получаемую клиентом, что является конкурентноспособным преимуществом для тех, кому проблематично отдать машину в сервис в будни. Такая же схема использована в рекламе строящегося клубного поселка:

3) Реклама строящегося жилья: Акция «Всё и сразу». Купил участок - лес в подарок! Продлеваем дачный сезон! Клубный поселок «Булгаковские дачи». 


\section{Побудительные конструкции с восклицательным знаком}

Также популярным приёмом постановки знаков препинания в креолизованном РТ являются побудительные конструкции, содержащие в себе призыв или заманчивое предложение. Подобные конструкции «придают живость и эмоциональность высказыванию, передают непосредственность разговорной речи» [Rozental', Kohtev 1981]. Чаще всего предикат в них выступает в роли императива, который побуждает совершить некое действие:

1) Реклама строящегося жилья: Акщиия «Въезжайте 2». Выцграй квартиру в Новом году! Жилой комплекс «Авиатор».

2) Реклама строящегося жилья: Живи в новом городе! Жилой комплекс «Риверсайд».

3) Реклама строящегося жилья: Ваш дом уже построен. Переезжайте на всё готовенькое! Квартиры от 1354000 руб. Микрорайон «Спутник».

Директивный тон восклицательных конструкций в РТ смягчается созданием иллюзии доверительного диалога на равных между рекламодателем и рекламополучателем, который наглядно иллюстрирует, что адресант «не обладает более высоким статусом по сравнению с адресатом, поэтому коммуникативное намерение говорящего (автора рекламы) идентифицируется как рекомендация, совет или просьба, а не приказ/команда» [Bolotina, Volkova 2012]. Подобные разговорные конструкции оказывают на целевую аудиторию эффективное воздействие. В тех восклицательных конструкциях, где восклицательный знак сопровождает заманчивое предложение, часто используется нулевая связка:

1) Реклама магазина спортивных товаров: Цены пополам! Спортмастер.

2) Реклама салона женского белья: MilaVitsa на реконструкции. ОТКРЫТИЕ В АПРЕЛЕ! Будут приятные сюрпризы!

Такой прием усиливает динамику РТ. Посредством восклицательной интонации транслируемое рекламное сообщение становится более эмоциональным, но его задача - лишь показать некий спектр эмоций, не обозначая какого-либо конкретного чувства.

\section{Многоточие}

Многоточие используется аналогично восклицательным конструкциям - для придания эмоциональности РТ. Однако, в отличие от восклицательного знака, 
многоточие передает иную палитру чувств. Известно, что А.Х. Востоков называл его в своей грамматике «знак пресекательный», который обозначал, что мысль прервалась, пресеклась. Н.С. Валгина, уже в XX веке, описывала его как емкий знак, который выполняет отделяющую функцию между предложениями и частями предложений, а также передает едва уловимые оттенки значений, подчеркивая как преднамеренный пропуск частей текста, так и делая акцент на скрытом подтексте и недосказанности, эмоциональном и психологическом напряжении, затрудненности и прерывистости речи [Valgina 1979]. Так, если в художественном тексте достаточно часто посредством данного знака передается ожидание, надежда, то в РТ в основном транслируется приятная неожиданность, интрига, легкий шок:

1) Реклама магазина джинсов: те самые ... настоящие джинсы Wrangler, Mustang, Lee, Montana.

2) Реклама строящегося жилья: А у нас в квартале... даже площадка для вылула собак! Квартал «Самоиветь»».

Многоточие, погружая в состояние предвкушения потрясающей новости, воздействует на целевую аудиторию и выгодно подчеркивает преимущества рекламируемого товара в сравнении с конкурентами.

Таким образом, приведенные примеры доказывают, что пунктуация играет большую роль в организации рекламных сообщений в качестве диалога на равных, который ведет рекламодатель со своей целевой аудиторией, а также придает экспрессивность и эмоциональность РТ. Несмотря на то, что мы не видим ответа рекламополучателя, ответная реакция на рекламное сообщение всегда существует, и она во многом зависит от общей композиции баннера, а также, в частности, от того, как пунктуационно организована вербальная часть.

\section{Литература}

Adamčik N.V., 1998, Bol'šoj anglo-russkij slovar', Minsk: Literatura.

Adâsova O.A., Gridina T.A., 2017, Reklama kak tekst vozdejstviâ: grafičeskij kod âzykovoj igry, Filologičeskij klass, 4 (50), pp. 37-43, https://cyberleninka.ru/article/n/reklamakak-tekst-vozdeystviya-graficheskiy-kod-yazykovoy-igry; 9.09.2019.

Bolotina M.A., Volkova I.S., 2012, Imperativ kak sredstvo vozdejstviâ v tekstah social'noj reklamy (na materiale russkogo i anglijskogo âzykov), Vestnik Baltijskogo federal'nogo universiteta im. I. Kanta. Seriâ: Filologiâ, pedagogika, psihologiâ, 2, pp. 7-12, https:// cyberleninka.ru/article/n/imperativ-kak-sredstvo-vozdeystviya-v-tekstah-sotsialnoyreklamy-na-materiale-russkogo-i-angliyskogo-yazykov; 13.09.2019.

Kupčinskaâ M.A., Ûdalevič N.V., 2019, Klipovoe myšlenie kak fenomen sovremennogo obŝestva, Biznes-obrazovanie v èkonomike znanij, 3 (14), pp. 66-71, https://cyberleninka. $\mathrm{ru} /$ article/n/klipovoe-myshlenie-kak-fenomen-sovremennogo-obschestva; 25.11.2020. 
LÈS: Ârceva V.N. (ed.), 2002, Lingvističeskij ènciklopedičeskij slovar', Moskva: Bol’šaâ rossijskaâ ènciklopediâ.

Maryšova M.A., 2012, Funkcii i semantika parcellirovannyh konstrukcij v âzyke reklamy, Izvestiâ Volgogradskogo gosudarstvennogo pedagogičeskogo universiteta, 70 (6), pp. 25-28, https://cyberleninka.ru/article/n/funktsii-i-semantika-partsellirovannyhkonstruktsiy-v-yazyke-reklamy; 9.09.2019.

Rozental' D.Ė., Kohtev N.N., 1981, Âzyk reklamnyh tekstov: učeb. posobie dlâ vuzov po spec. «Žurnalistika», Moskva: Vysšaâ škola.

Valgina N.S., 1979, Russkaâ punktuaciâ: principy i naznačenie, Moskva: Prosveŝenie.

Voejkova A.A., 2015, Strukturno-funkcional'nye osobennosti voprositel'nyh predloženij (na primere tekstov russkoj reklamy), Vestnik Tomskogo gosudarstvennogo pedagogičeskogo universiteta, 6 (159), pp. 113-117, https://cyberleninka.ru/article/n/strukturnofunktsionalnye-osobennosti-voprositelnyh-predlozheniy-na-primere-tekstov-russkoyreklamy; 11.09.2019.

Zaharova E.O., 2009, Punktuacionnye i punktuacionno-grafičeskie priemy reklamnogo teksta, Vestnik Tomskogo gosudarstvennogo pedagogičeskogo universiteta, 324, pp. 25-28, https://cyberleninka.ru/article/n/punktuatsionnye-i-punktuatsionno-graficheskiepriemy-reklamnogo-teksta; 9.09.2019. 